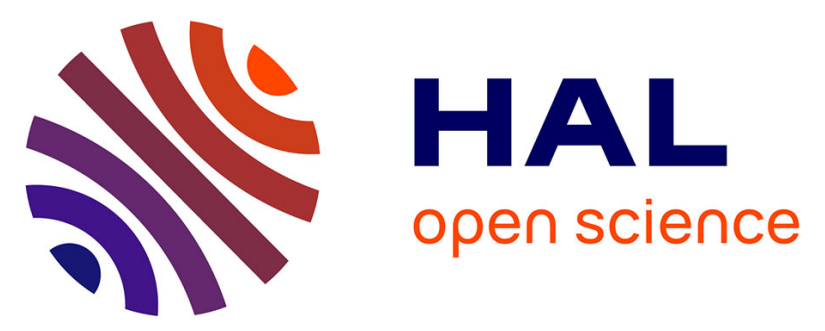

\title{
Improving identification of coppiced and seeded trees in past woodland management by comparing growth and wood anatomy of living sessile oaks ( Quercus petraea )
}

Olivier Girardclos, Alexa Dufraisse, Jean-Luc Dupouey, Sylvie Coubray, Julien Ruelle, Cyrille Rathgeber

\section{To cite this version:}

Olivier Girardclos, Alexa Dufraisse, Jean-Luc Dupouey, Sylvie Coubray, Julien Ruelle, et al.. Improving identification of coppiced and seeded trees in past woodland management by comparing growth and wood anatomy of living sessile oaks ( Quercus petraea ). Quaternary International, 2017, 463 (In press), pp.1-13. 10.1016/j.quaint.2017.04.015 . hal-01525878

\section{HAL Id: hal-01525878 \\ https://hal.science/hal-01525878}

Submitted on 17 Nov 2017

HAL is a multi-disciplinary open access archive for the deposit and dissemination of scientific research documents, whether they are published or not. The documents may come from teaching and research institutions in France or abroad, or from public or private research centers.
L'archive ouverte pluridisciplinaire HAL, est destinée au dépôt et à la diffusion de documents scientifiques de niveau recherche, publiés ou non, émanant des établissements d'enseignement et de recherche français ou étrangers, des laboratoires publics ou privés.

\section{다(1)(2)}

Distributed under a Creative Commons Attribution - ShareAlikel 4.0 International 


\title{
Improving identification of coppiced and seeded trees in past woodland management by comparing growth and wood anatomy of living sessile oaks (Quercus petraea)
}

\author{
Olivier Girardclos ${ }^{\text {a, }}{ }^{*}$, Alexa Dufraisse ${ }^{\text {b }}$, Jean-Luc Dupouey ${ }^{\mathrm{d}}$, Sylvie Coubray ${ }^{\mathrm{b}, \mathrm{c}}$, \\ Julien Ruelle ${ }^{\mathrm{d}}$, Cyrille B.K. Rathgeber ${ }^{\mathrm{d}}$ \\ a Chrono-Environnement, CNRS-University of Bourgogne-Franche-Comté, UMR 6249, 16 route de Gray, F-25030, Besançon cedex, France \\ b Sorbonne Universités, CNRS, Muséum national d'Histoire naturelle, UMR 7209, Archéozoologie, Archéobotanique: sociétés, pratiques et environnements, \\ CP56, 55 rue Buffon, 75005 Paris, France \\ ' INRAP, Centre-île de France, 41 rue Delizy, 93690 Pantin cedex, France \\ ${ }^{\mathrm{d}}$ LERFoB, INRA, AgroParisTech, F-54000, Nancy, France
}

\section{A R T I C L E I N F O}

Article history:

Received 14 June 2016

Received in revised form

29 March 2017

Accepted 12 April 2017

Available online $\mathrm{xxx}$

\section{Keywords:}

Dendrochronology

Dendro-anthracology

Deciduous oak

Coppice

Past woodland management

\begin{abstract}
A B S T R A C T
Written sources and archaeological evidence suggest that coppicing was a common practice in past woodland management. Depending mainly on the length of rotations, coppices provided wood products of various sizes, and coppice-wood has been identified in fuel-wood remains as well as in timber studies. Assigning the origin of the wood analyzed to coppice is based on observation of "typical growth patterns": an even-age structure and a rapid decrease in ring-width with age are used nowadays. However, the wide variety of coppice practices and the variability observed in living-tree analogs make it difficult to draw definitive conclusions. To contribute to improving coppice-wood identification, the present study analyzed differences in growth and tree-ring anatomy between living sessile oaks from a mixed stand of coppiced and seeded trees.

Stems were compared based on ring-width, early- and late-wood widths, number and size of the earlywood vessels, and tissue proportions measured at different heights. The growth of coppiced trees was found to be faster than that of seeded trees, in height at cambial ages between 3 and 5 years and in diameter at 5-8 years. A quantitative anatomy study showed that tree rings from coppice shoots had smaller and more numerous vessels per unit surface area and a weaker hydraulic conductivity. Earlywood width, which can be acquired on archaeological wood much more easily than vessel surface, was significantly greater in the sample of seeded trees. Linear discriminant analysis performed on the data used to model earlywood width (leave-one-out procedure) correctly classified $77 \%$ of coppice and $54 \%$ of seeded trees when the radius exceeded $1.66 \mathrm{~cm}$ and offers promising perspectives for dendroanthracology and dendrochronology. Growth and anatomical differences between coppiced and seeded trees mixed in the same stand were observed while other sources of variability (site condition, competition, species) were constrained.
\end{abstract}

๑) 2017 Elsevier Ltd and INQUA. All rights reserved.

\section{Introduction}

Coppicing is a widespread practice in woodland management that takes advantage of the capacity of numerous woody plants to regrow after one or more cuts (e.g. Duhamel du Monceau, 1764, Rackham, 2003). As shown by Clarke et al. (2013) literature

\footnotetext{
* Corresponding author.

E-mail address: olivier.girardclos@univ-fcomte.fr (O. Girardclos).
}

review, resprouting ability is determined by the development, protection and resourcing of a viable bud bank, after fire and other dramatic disturbance events such as flooding or wind storms (Bond and Midgley, 2003). In an anthropized environment, coppicing harnesses this resprouting ability in order to manage stand recovery between repeated cuts, typically every 5-30 years (e.g. Duhamel Du Monceau, 1764). After felling, resprouting involves the activation and supplying of dormant vegetative basal buds (Clarke et al., 2013). Supplying bud development after damage of the aboveground part of the plant requires the mobilization of 
resources; this is achieved by the translocation of carbohydrate reserves from underground portions of the trunk and/or root system (Del Tredici, 2001). In a large number of angiosperms, resprouting ability after felling differs with the stage of tree development (Clarke et al., 2013). For Quercus petraea, which was selected for the present study because of its present and past abundance in France and more widely in Europe, resprouting is possible but the probability decreases with stump diameter and age (Splichalova et al., 2012). Stand dynamics such as dead stumps and residual tree densities also affect the fine-scale spatial patterns of oak sprouting (Svatek and Matula, 2015). Unearthing the root system of coppiced Quercus pyrenaica allowed Salomón et al. (2013, 2016) to study belowground organs, carbohydrate reserves and their relations with aboveground dynamics. Carbohydrate reserves were found to be higher in roots before buds burst, but stems belonging to old large root systems had a lower growth potential than those with a smaller belowground biomass. Vigorous initial growth of coppice shoots has been reported (Burns and Honkala, 1990; Splichalova et al., 2012), while at stand level Crockford and Savill (1991) indicated that their yield tables for oak coppice were quite similar to those expected from a conventionally spaced plantation. The remains after felling of belowground biomass and carbohydrate reserve translocation can be considered as the main factors differentiating the life histories and growth strategies of sprouts from coppiced and seeded trees in the same stand conditions.

The first goal that coppice management attempts to achieve is a sustainable supply of relatively thin diameter stems on relatively short rotations compared to e.g. high-forest (Del Tredici, 2001; Splichalova et al., 2012). The main coppice extensions at woodland level in medieval and post-medieval times as documented in numerous written sources in France (Duhamel du Monceau, 1764, Corvol-Dessert, 2002; Buridant, 2004) and more generally in Western Middle Europe (Rackham, 2003) can be first related to firewood supply. However, studying the interactions between human societies and woodland vegetation during the past millennium from a palaeoecological perspective requires taking a larger variability of practice into consideration. Based on yield tables results, Crockford and Savill (1991) considered that coppice rotations were determined more by the size of the end product required than by any consideration of maximizing productivity. Depending on local settings, thinning and harvesting practices, felling age or species selection, coppices can yield material of differing dimensions and specificity. Archaeological studies of wood remains provide material evidence of the diversity of wood products over time and several recent studies have argued that some of them may have derived from coppices at different periods. For instance, the timber supply in several Neolithic pile-dwelling settlements may have come from coppices (Billamboz, 2012, 2014; Bleicher, 2007). A Late Bronze Age fishweir complex of post-and-wattle fences was made using first time harvested alders and was repaired using coppiced stools (Bernard et al., 2012). Coppices are believed to have been an importance source of building timber in Medieval and post-medieval logging (Haneca et al., 2006; Epaud and Bernard, 2008) and of firewood (Davasse, 2000; Nelle, 2002; Dufraisse and Gauthier, 2002; Deforce et al., 2013; Deforce and Haneca, 2015; Paradis-Grenouillet et al., 2015, Dupin et al. this volume).

The arguments for assigning the origin of wood remains to coppice in these studies are in part specific to the conditions of each site, often refer to comparisons with the general or measured characteristics of living trees, and mainly depend on the possibility of interpreting tree-ring series or not. Analysis based on tree-ring patterns of charcoal fragments - often consisting of only a few rings - is termed dendro-anthracology. This technique is used to reconstruct forest stand structure by estimating the frequencies of radius/diameter size classes and average growth rate (Nelle, 2002; Marguerie and Hunot, 2007; Marguerie et al., 2010; Dufraisse and Garcia-Martinez, 2011; Dufraisse et al., this volume). Dendrotypological classifications have been mainly applied to waterlogged building timber as this provides longer tree-ring series and assemblages of numerous samples. These classifications are based on groups using multi-criteria analysis of archaeological observations and growth patterns at tree level and/or stand level if time relations between cross-dated series can be used (coincidence of felling dates, synchronicity of biotic signals such as insect damage, Billamboz, 2003, 2012, 2014). Reconstruction of the harvested forest structure is one of the main aims of dendrotypology and the three criteria of (1) a relative standardization of diameters and agreement between log and final product, (2) even-age structure and (3) vigorous initial growth, currently provide the most direct characterization of the coppice origin of ancient wood (Billamboz, 2003, 2012; Haneca et al., 2006; Girardclos et al., 2012; Deforce and Haneca, 2015). A unimodal diameter distribution argues in favor of the homogeneity of the dimensions of the trees harvested. By counting rings, taking into account pith offset, it is possible to determine the homogeneity of the felling age. In the cited studies, "vigorous initial growth" means wide rings from near the pith to 5-10 years, followed by a more or less sudden decrease. The chronological relationship between felling and resprouting dates has been used only in favorable situations after cross-dating of series (Bernard et al., 2012; Billamboz, 2014).

While many studies refer to characteristics observed in presentday forest, analyses of living trees from an archaeological perspective are still too scarce to take potential regional and temporal variabilities of coppices into account (Deforce and Haneca, 2015), and results are sometimes divergent (Copini et al., 2010). Comparisons with other stand structures such as high-forest (Haneca et al., 2006; Girardclos et al., 2012; Deforce and Haneca, 2015) are also too scarce to ascertain the specificity of coppice growth patterns and support it as evidence while wood retrieved in different ancient contexts can potentially come from a mixture of forest stands.

At present, there are no studies comparing the growth and wood anatomy of coppiced and seeded living oaks developing in the same stand. The goals of our investigation were therefore to quantify the assumed growth differences in this new situation, the resulting wood anatomy and to express these differences in quantitative terms allowing a better distinction of ancient oak wood from both firewood and timber studies belonging to either coppice or seedling-based stand managements. The analysis of ancient wood remains is subject to several constraints, in particular 1) sampling height in the tree, which is potentially different for fuel-wood fragments and can be estimated only for timber preserved over a great length, 2) firewood fragments often present only a small number of rings. To take the first constraint into account, our sampling design included separate heights in living trees. To take the second constraint into account and improve standard dendrochronological techniques based on ring-width analysis, growth pattern descriptions were supplemented with anatomical variables. Earlywood width around the pith has been suggested as a more consistent measure to identify wood of coppice origin since ring-width variations are considerable in coppiced pedunculate oaks growing under similar conditions (Copini et al., 2010). However, the area of vessels in earlywood is also known to present high variability between individuals and to be highly related to cambial age in the juvenile phase regardless of growth strategy which could have consequences on a potential wood of coppice origin identification (Huber, 1993; Fonti et al., 2009).

Our underlying biological assumption is that the presence of belowground biomass is an important trait of sprouts' life history, 
whatever the historical period, and affects their growth strategy. The following questions were addressed to achieve the aims. For how long after felling do coppice shoots grow faster than seeded trees in both height and radial directions? Are there quantitative wood anatomical differences resulting from the two life-histories? Can the observed anatomical differences contribute to identifying wood originating from coppiced or seeded trees in the studied samples, considering the constraints of archaeological wood analysis techniques?

\section{Material and methods}

\subsection{Regional setting}

Oak was selected for the study because this taxon is often encountered on archaeological sites in Western Europe. As previous studies showed differences in radial growth (Becker et al., 1994) and wood anatomy (Feuillat et al., 1997) between the two most abundant species of oak in the region, Quercus petraea and Quercus robur, we focused on a pure stand of sessile oak. The differences between the two growth strategies were studied, keeping other factors, including species, as constant as possible because no previous study describes wood anatomy of coppiced and seeded oaks. Careful consideration, based on GIS information, National Forest Inventories and field visits, was given to identify a mixed stand containing coppice and seeded trees of very similar dimensions and local conditions. The stand studied is located in France, N49 ${ }^{\circ} 50^{\prime} 55.4^{\prime \prime}$, E004 $42^{\prime} 08.9^{\prime \prime}$ near the town of Charleville-Mézières at low altitude (340 $\mathrm{m}$ a.s.l.) in the Ardennes Mountains (Fig. 1A).

\subsection{Stand setting}

The studied stand grows on an acidic brunisol developed on a schistous substrate. The sandy loam texture with a low rate of gravel up to $70 \mathrm{~cm}$ deep offers low constraints. The sessile oak stand can be considered pure since the total cover-abundance of birch (Betula pendula), rowan (Sorbus aucuparia), holly (Ilex aquifolium) and beech (Fagus sylvatica) is less than $20 \%$; the absence of Qu. robur was verified.

The silvicultural itinerary of the stand is a recent conversion of coppice to high forest. A clear cut was performed during the winter 1993-1994. In 1995 the forestry managers decided to plant 2-yearold trees from a nursery due to a lack of self-seeding oaks. In the stand coppiced and seeded trees can be easily distinguished by the following morphological characteristics: multi-shoots and a low stump height above ground against a single stem and a cylindrical smooth collar (pictures on Fig. 1B and C). Indeed, it is impossible to totally exclude the presence of trees which have only a single stem but are in fact "seedling sprouts", i.e. sprouts arising from an older root collar zone. According to the studies reviewed by Del Tredici (2001), depending on overstory conditions or grazing events, these "seedling sprouts" can occur in nearly $20 \%$ of seedlings. Evenage structure was verified by taking 20 cores with a Pressler type borer of both coppice shoots and planted trees. In 2011, the oak trees were $12-15$ years old at $1 \mathrm{~m}$ high based on simple ring count. In accordance with the silvicultural objective of conversion to high forest, the stand had been thinned and only the largest single shoot was allowed to further develop, but other shoots were trimmed at ca. $1 \mathrm{~m}$ high (Fig. 1B).

Dendrometric records were taken in two sample plots of $230 \mathrm{~m}^{2}$ and $540 \mathrm{~m}^{2}$. Diameter over bark was measured at breast height, in the smaller plot of all stems above one meter high and in the larger plot of stem diameters above $7.5 \mathrm{~cm}$. Total height was measured on dominant oaks, defined as the 100 largest diameters per hectare, which meant here 5 stems. Based on these records, stocking was estimated to be close to 6000 stems of all diameters per hectare, of which 1075 stems above $7.5 \mathrm{~cm}$ in diameter, and the total basal area reached $14 \mathrm{~m}^{2} / \mathrm{ha}$. Quadratic mean diameter, which is the arithmetic mean of the mean basal area stem, reached $5.5 \mathrm{~cm}$ and dominant height was $9.1 \mathrm{~m}$ for trees with a mean diameter of $11 \mathrm{~cm}$.

\subsection{Tree selection strategy}

The goal was to sample stems that were very similar in dimensions and vitality from the two growth strategies, from both
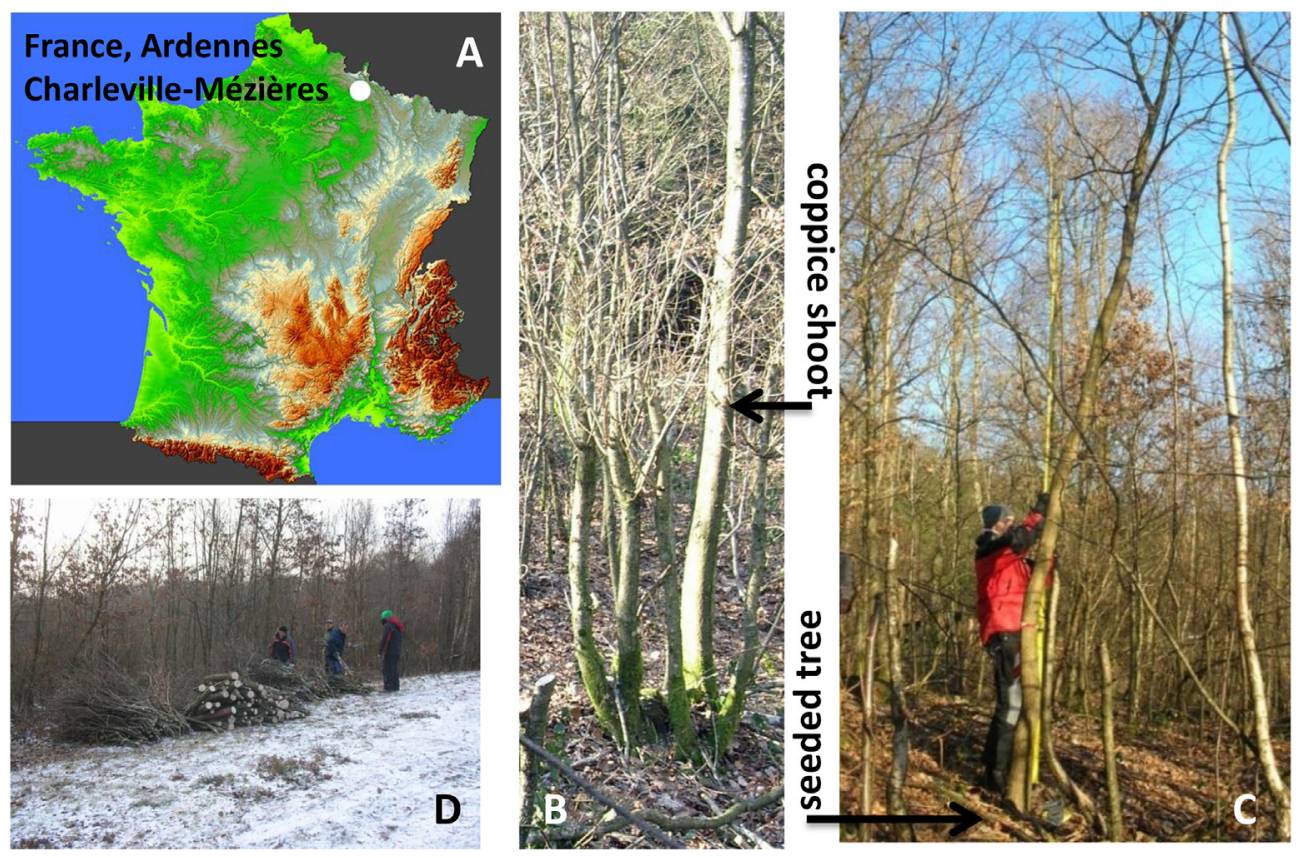

Fig. 1. A: Map of France with the site location. B: Illustration of a sampled coppiced stump. C: Illustration of a sampled seeded tree. D: Illustrations of the stand. 
coppiced and seeded trees. To achieve this goal dendrometric measures and cores from 10 candidate trees per category were compared with one another as well as with stand records. Dominant trees were excluded and among the 20 candidates 5 stems were selected per group, based on diameter, total height, crown height and ground projection, age and mean width of the 5 outermost rings. Average diameter at breast height of the 10 stems analyzed was slightly over $10 \mathrm{~cm}$ for a total height between 8.5 and $8.8 \mathrm{~m}$. Fig. 2 shows that the 2 groups of trees are very close for all the selected variables both in stem and crown characteristics. Differences between the means averaged for the seeded and coppiced groups are not significant at the $\mathrm{p}<0.05$ level as tested by a twotailed $t$-test.

\subsection{Data acquisition protocol}

During winter 2011 the selected trees were harvested and registered at $1 \mathrm{~m}$ intervals along the stem (Fig. 1D). Two discs, each a few centimeters thick, were sawn each meter, one for the reconstruction of height evolution and radial increment with age based on ring-width measurements, stem analysis (Payette and
Delwaide, 2010) and for early/late wood (EW/LW) widths measurements, and the second for quantitative anatomical analysis (Fig. 2A).

After the discs had been air-dried and sanded using progressively finer sandpapers, RW was measured to the nearest $0.01 \mathrm{~mm}$ using a LINTAB measurement device and associated TSAP software (Rinn, 1989). On each disc, RW was measured along 5 radii: 1) north direction materialized in the field (this was constant), 2) along the largest distance between cambial zone and pith, 3) along the smallest distance, generally opposed to the previous one, and 4) and 5) along 2 "normal" distances, generally perpendicular to the previous ones. Visual cross-dating of the 5 radii and between trees RW series was checked with the help of the function "test toward rest of the collection" of the C-Dendro software (L. Larsson http:// www.cybis.se/forfun/dendro/). The correlation coefficient was calculated between detrended ring-width series from each radius and the mean chronology excluding the tested series. For lower values of this coefficient it was carefully verified that the reason for the low correlation was anatomical features and not a measurement error or a misunderstood ring boundary. The same protocol was followed to establish EW and LW width series, but only for the

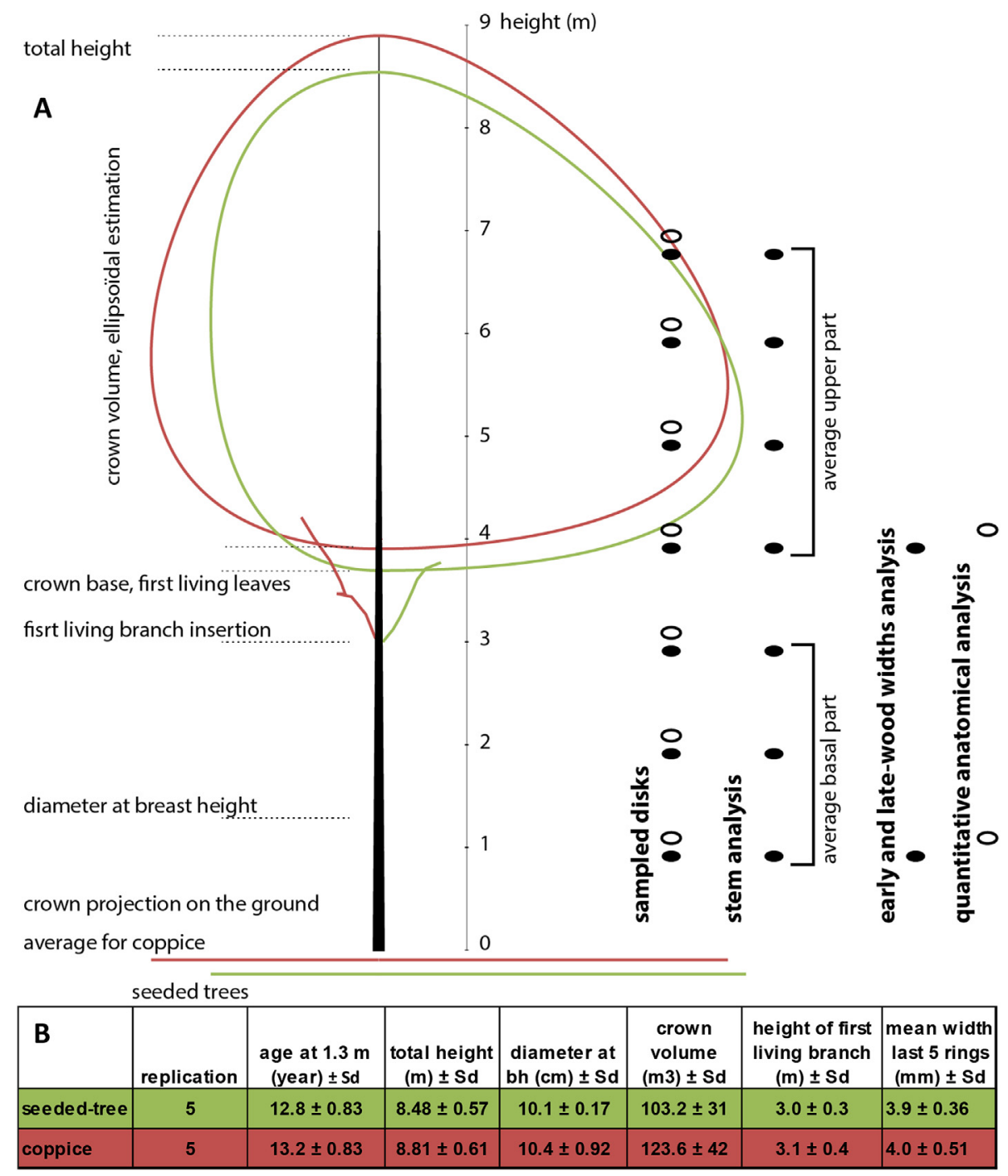

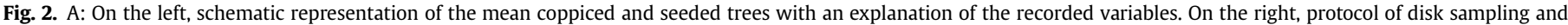

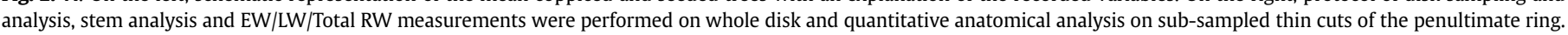
B: Means and standard deviation of the main characteristics for the coppiced and seeded tree groups sampled. 
discs taken from $1 \mathrm{~m}$ and $4 \mathrm{~m}$ high (Fig. 2A).

For quantitative anatomical analysis, a total of 20 samples were collected from the disks sampled on the field at $1 \mathrm{~m}$ and $4 \mathrm{~m}$ high in the 5 coppice and 5 seeded trees (Fig. 2A). Wood strips ( $2 \mathrm{~cm}$ wide) parallel to the radial file were sawn in the lab. These samples were embedded in PEG and then sections of about $15 \mu \mathrm{m}$ thickness were cut with a slide microtome. Cross sections were rinsed with distilled water, stained for $1 \mathrm{~min}$ in Safranine $\mathrm{O}$ solution $(1 \% \mathrm{w} / \mathrm{v})$, treated with hydrochloric acid and rinsed with distilled water. These sections were double stained with astra blue $(1 \% \mathrm{w} / \mathrm{v})$ for $5 \mathrm{~min}$, rinsed with distilled water before dehydration with $96 \%$ ethanol multiple times, then with absolute ethanol. Finally they were dipped in solvent (Histoclear, National Diagnostics, Atlanta, Georgia) before mounting in Histolaque LMR $^{\odot}$. We used a digital camera (Sony XCD-U100CR) mounted on a light microscope (Zeiss AxioImagerM2) to capture images of the cross sections. Image analyses were conducted with ImageJ 1.49 software (http://rsb.info. nih.gov/ij/) to determine various anatomical features in the penultimate ring of the tree, i.e. vessel diameter $(\mu \mathrm{m})$ and density (vessel number per $\mathrm{mm}^{-2}$ ). Very similar stems from the two groups were selected on the basis of a field estimation of the mean width of the 5 outermost rings. Among these rings, the penultimate ring was chosen for technical reasons and in order to compare rings from the two groups formed the same calendar year and close in cambial age.

Hydraulic conductivity was calculated following (Tyree and Ewers, 1991):

$K_{h}=\frac{\pi \rho}{128 \eta} \sum_{i=1}^{n}\left(d_{i}^{4}\right)$

where $K_{h}$ is the hydraulic conductivity, $\rho$ is the liquid density $\left(998.21 \mathrm{~kg} \mathrm{~m}^{-3}\right.$ ), $\eta$ the viscosity of the fluid (for water $=1.002$ $\times 10^{-9} \mathrm{MPa} \mathrm{s}^{-1}$ at $\left.20^{\circ} \mathrm{C}\right), d$ is the vessel diameter $(\mathrm{m})$ and $n$ the number of vessels of the ring. To include the effects of both vessel diameter and vessel density, stem specific hydraulic conductivity $\left(K_{s} ; \mathrm{kg} \mathrm{m}^{-1} \mathrm{~s}^{-1} \mathrm{MPa}^{-1}\right)$ of the stem section was calculated by multiplying $K_{h}$ by the mean number of vessels per $\mathrm{m}^{2}$ of the transverse cross-sectional area of the sample (Tyree and Ewers, 1991).

\subsection{Data analysis}

All the data analysis was processed using the programing language $\mathrm{R}$ (version 3.2.2, R Foundation for Statistical Computing, Vienna, Austria) using descriptive statistics on the basis of a $5 \%$ significance level.

Depending on the normality distribution, Student's t or KruskalWallis tests were performed to compare the anatomical features of the two groups obtained by image analysis of the penultimate ring.

For the time series of EW and LW widths and LW percentage significant differences among the two groups were tested according to the following univariate linear model.

$\mathrm{X}_{\mathrm{hijk}}=\mu+\mathrm{b}_{\mathrm{i}}+\mathrm{c}_{\mathrm{j}(\mathrm{i})}+\mathrm{H}_{\mathrm{h}}+\mathrm{RW}_{\mathrm{hijk}}+\mathrm{r}_{\mathrm{hijk}}+\varepsilon_{\mathrm{hijk}}$

where $\mathrm{X}_{\mathrm{hijk}}$ is EW and LW widths or LW percentage measured on the ring $\mathrm{k}$ of the disk $\mathrm{h}$ of the tree $\mathrm{j}$ from live history $\mathrm{i}, \mu$ is a constant term, $b_{i}$ represents the effect of the category $i$ of live history (coppiced or seeded oak), $\mathrm{c}_{\mathrm{j}(\mathrm{i})}$ is the effect of tree $\mathrm{j}$ within the live history $\mathrm{i}, \mathrm{H}_{\mathrm{h}}$ is the category $\mathrm{h}$ of disk height (1 or $4 \mathrm{~m}$ ), $\mathrm{RW}_{\text {hijk }}$ is ring-width of the ring where $X$ were measured, $r_{\text {hijk }}$ is current radius where $\mathrm{X}$ were measured, and $\varepsilon_{\mathrm{hijk}}$ is an error term.

The aim of our modeling was to identify in EW width, LW width and LW percentage the main variable to discriminate between coppice and seeded trees taking into account ancient wood analysis constraints. In equation [1], current radius was preferred as the explicative variable to cambial age and calendar date which are more widely used in tree-ring analysis, because only radius estimation is accessible in ancient charcoal analysis. Moreover, in our dataset, cambial age is highly correlated with radius $(r=0.97)$, and $r$ is 0.72 between calendar date and cambial age because of evenage structure. The effects of cambial age and calendar date on dependent variables were also tested instead of current radius $\left(r_{\text {hijk }}\right)$ in the presented model.

The model performance in assigning the right live history category, coppiced or seeded tree, was tested using variables selected on the basis of the quantitative anatomical analysis, modeling results and the suitability for dendro-anthracological purposes. Calculation was performed with the $\mathrm{R}$ package MASS (Venables and Ripley, 2002) following a leave-one-out procedure.

\section{Results}

\subsection{Height and radial growth patterns}

The relationship between height and tree age showed a linear pattern for coppiced stems and a more sigmoid pattern for the seeded ones (Fig. 3A). Tree age was estimated by counting rings on the disk taken at $1 \mathrm{~m}$ high, namely cambial age at $1 \mathrm{~m}$, and thus can be considered as similar to a classical estimation done by coring trees at breast height. During the first five years, the increase in height per year was about $0.7 \mathrm{~cm}$ for coppice and nearly $0.5 \mathrm{~cm}$ for seeded trees. The greatest difference, $0.75 \mathrm{~cm}$, was observed at 4 years when coppiced shoots were nearly $3.25 \mathrm{~m}$ high while seeded trees were $2.5 \mathrm{~m}$. Differences between the seeded and coppiced mean heights were tested following a two-tailed pairwise $t$-test at the 0.05 significance level, independently for each age. Coppice height was significantly greater between 3 and 5 years. From the ages of 5-8 years, the annual height increment of seeded trees increased to ca. $0.7 \mathrm{~cm}$ and finally from 8 years to the age of sampling the heights of the two categories were similar. The relation between diameter, estimated cumulated ring-width measurements at $1 \mathrm{~m}$ high, and age showed the same linear pattern for coppice and a more sigmoid pattern for seeded trees (Fig. 3B). However the annual increment increase was observed in seeded trees after a longer time-lag of 3-4 years. The diameter increased by nearly $0.60 \mathrm{~cm}$ per year in coppice; in seeded trees it began at around $0.45 \mathrm{~cm}$ reaching $0.85 \mathrm{~cm}$ when the trees were 9 years old. The greatest difference was observed at 8 years and the diameter was significantly higher for coppice between 5 and 8 years. When tree age reached 11 years, the diameter of the two categories was no longer different.

The relation between ring-width and age provides details about the annual radius increment (Fig. 3C). Ring-widths were averaged according to the 5 radii and cambial age for discs from 1 to $3 \mathrm{~m}$ high to give a more general representation of the base of the stem under the crown (Fig. 2A). The two categories did not exhibit the same trend. Tree-ring patterns can be divided into three periods that can be related to the more linear or sigmoid growth trends observed in height and diameter. 1) Between 2 and 8 years old, ring-widths increased slowly and coppiced shoots developed wider rings than seeded trees. A wide variation was observed, especially for the first 3 rings, and the difference was significant only for the years 5 and 6 . 2) Between 9 and 12 years old, seeded trees' productivity rapidly increased and remained higher than coppice. The difference was significant for the years 9 and 11. 3) After 12 years old, ring-width started to decrease, more rapidly for seeded trees.

The tree-ring patterns described above for the base underwent 


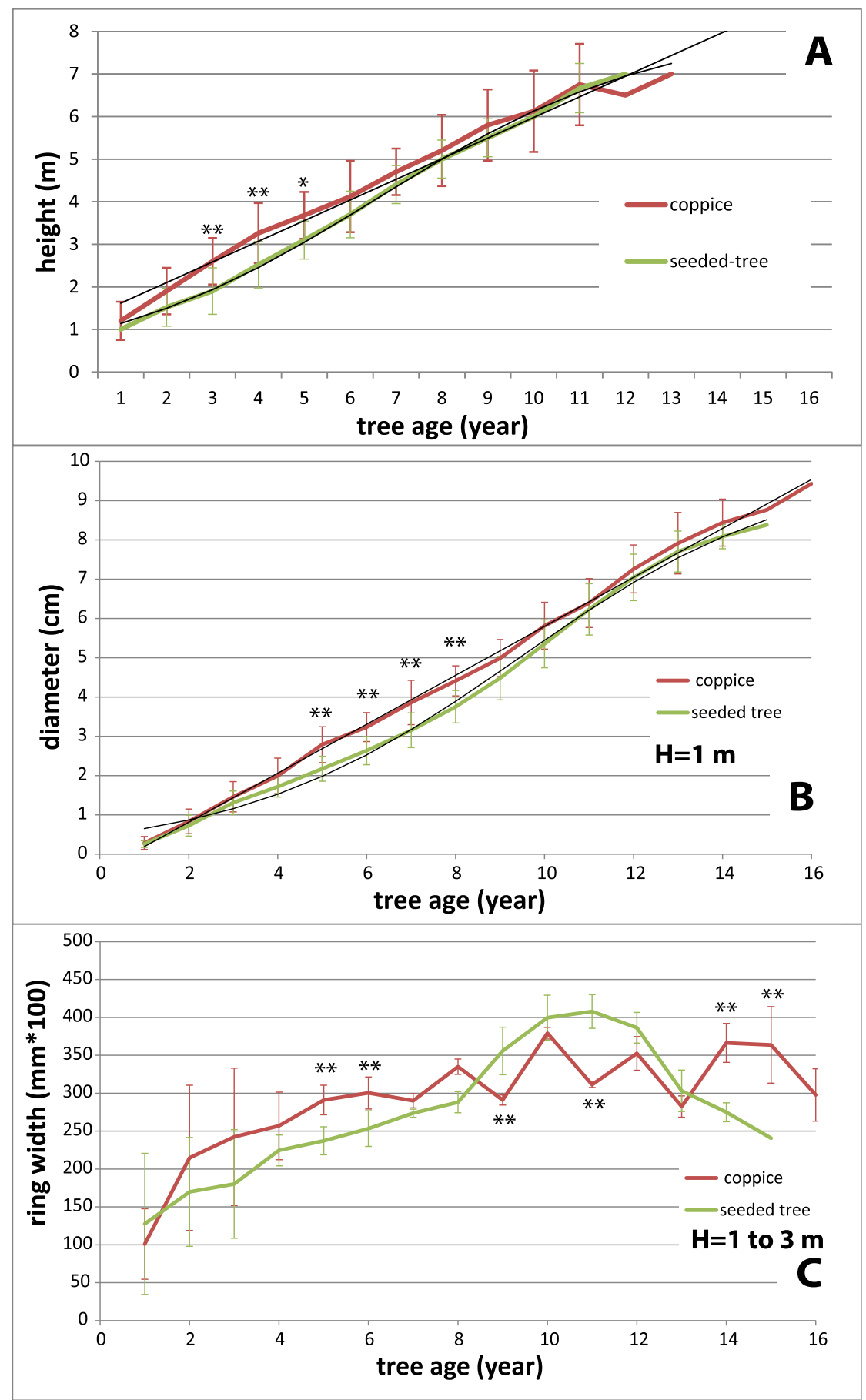

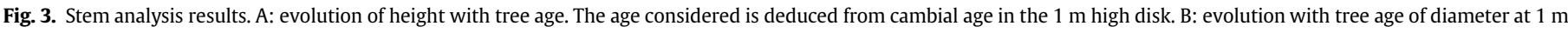

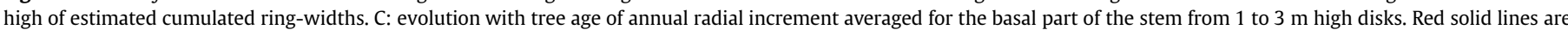

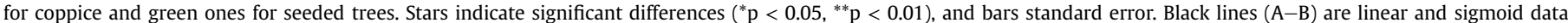
adjustments. (For interpretation of the references to colour in this figure legend, the reader is referred to the web version of this article.)

changes higher in the stem. For a more general representation of the upper part of the stem, data were averaged according to the cambial age of disks taken at a height of 4-7 m. For all the studied trees this height was greater than the height of the first living leaves and thus corresponded to the main axis in the crown (Fig. 2A). Generalized in this way, no difference was observed in the relationships of diameter (Fig. 4A) and ring-width (Fig. 4B) to cambial age between coppiced and seeded trees for the upper part of the stem.
Fig. $4 \mathrm{C}$ gives the relationships between tree age at $1 \mathrm{~m}$ high and ring-width averaged for the basal and for the upper part of the stem. The three periods defined in the basal part can be distinguished for both coppiced and seeded trees in the upper one, but differences are not significant.

\subsection{Quantitative anatomical analysis, penultimate ring patterns}

The results are shown only for variables for which differences 

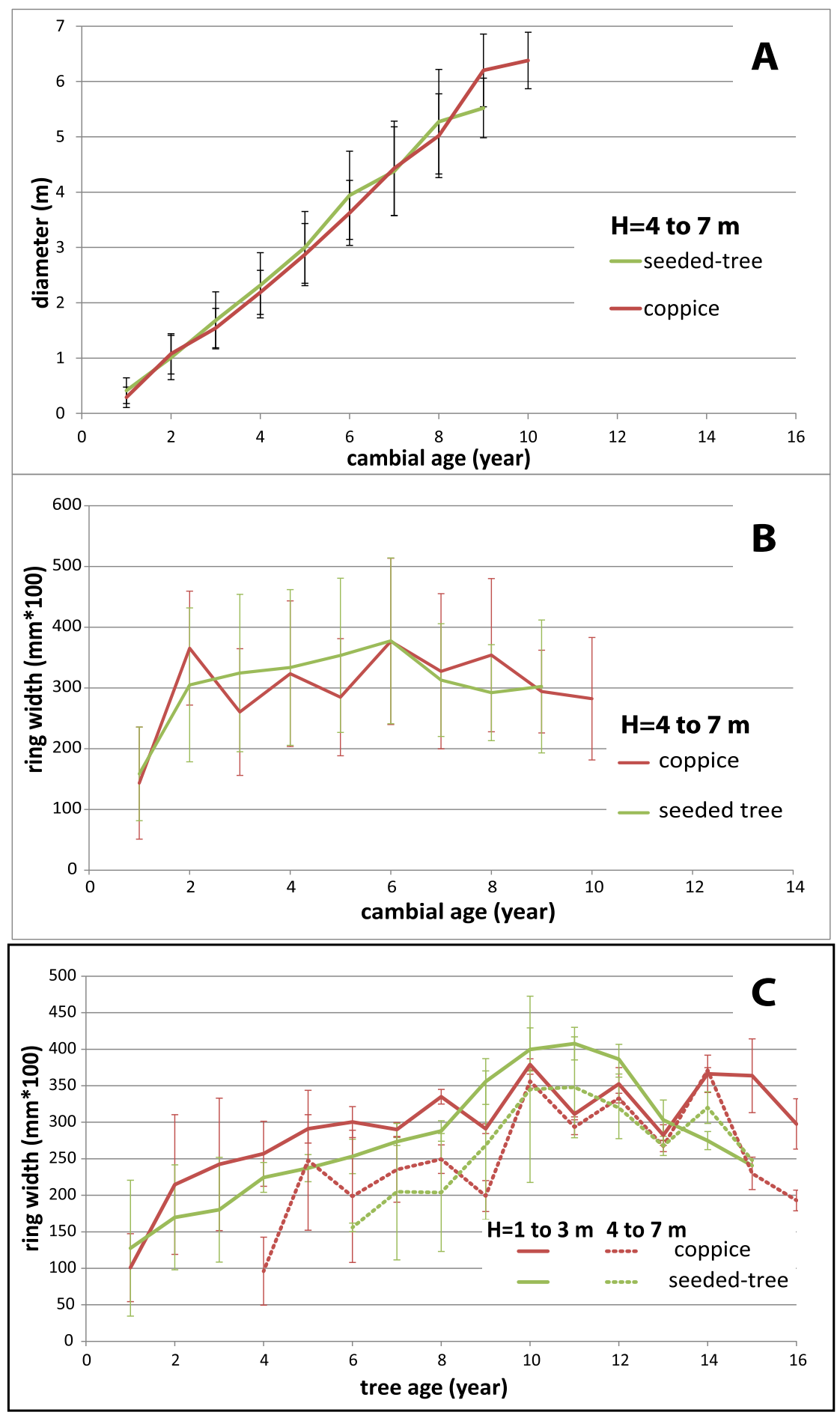

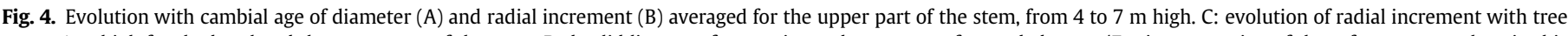

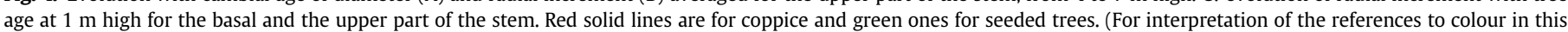
figure legend, the reader is referred to the web version of this article.)

among the two categories are significant regardless of sample height origin ( $1 \mathrm{~m}$ and $4 \mathrm{~m}$ high) to be closer to anthracological analysis; all of them concern vessels. As illustrated by contrasting examples of thin cuts (Fig. 5A), vessel size distributions were marked by a higher proportion of large vessels, over $10^{3} \mu \mathrm{m}^{2}$, for seeded trees while coppice ring anatomy was dominated by numerous small vessels (Fig. 5B). The number of vessels per surface unit was higher for coppice (Fig. 5C) but their total surface median proportion reached $9 \%$, lower than that of seeded trees $(12 \%$,
Fig. 5D). Consistent with the total vessel surface proportion, mean stem specific hydraulic conductivity, which includes the effects of both vessel diameter and vessel density, was weaker for coppice: $45.4 \mathrm{~kg} \mathrm{~m}^{-1} \mathrm{~s}^{-1} \mathrm{MPa}^{-1}$ than for seeded trees: $96.5 \mathrm{~kg} \mathrm{~m}^{-1} \mathrm{~s}^{-1} \mathrm{MPa}^{-1}$.

\subsection{Early and late wood width series modeling}

EW and LW widths were measured and LW percentage of total 

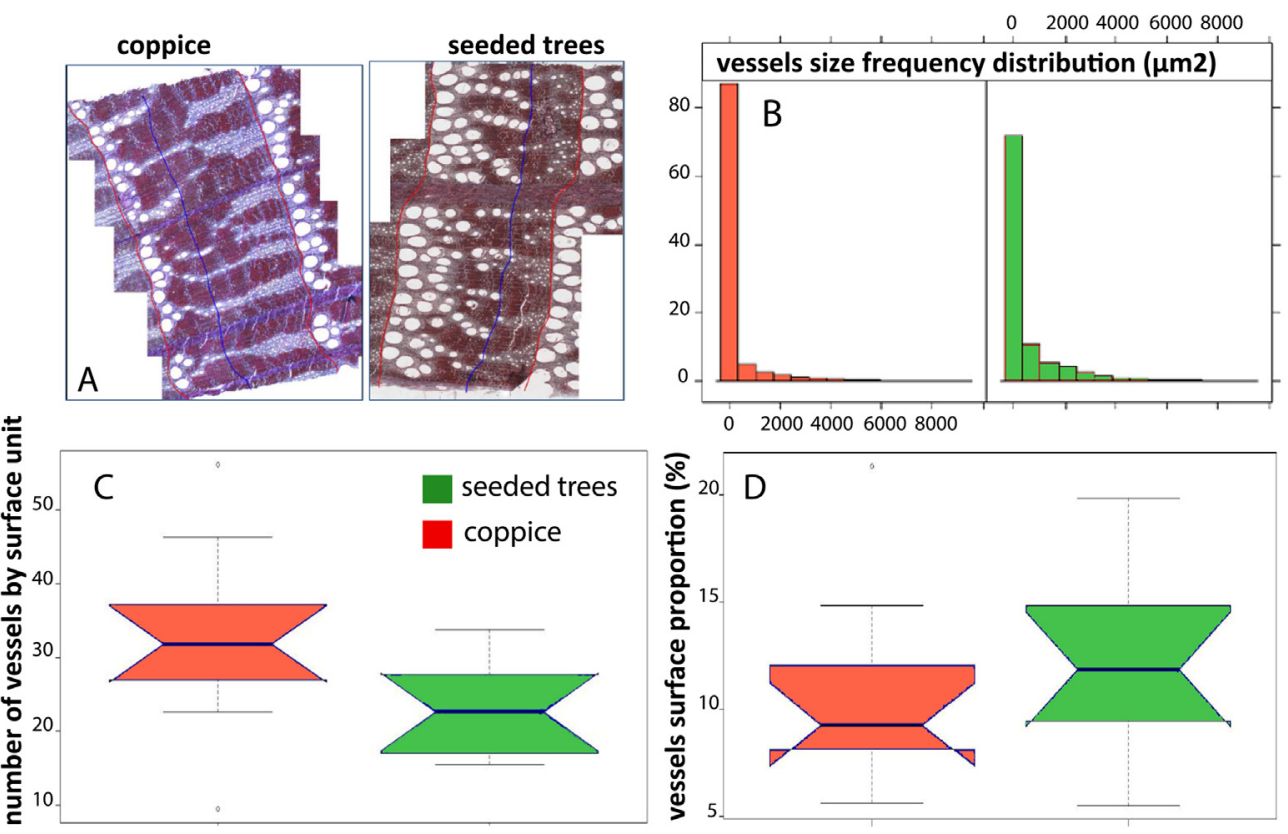

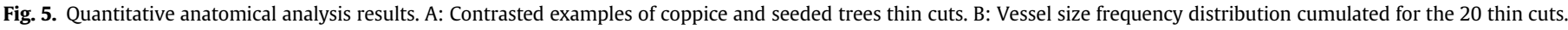

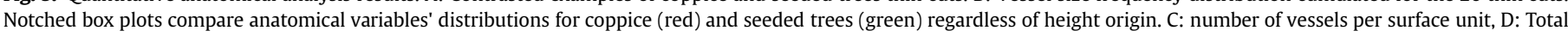
surface proportion of vessels for each ring. (For interpretation of the references to colour in this figure legend, the reader is referred to the web version of this article.)

RW was calculated on a total number of $\mathrm{N}=211$ rings. Cambial age ranged from 1 to 15 years at $1 \mathrm{~m}$ high and $1-9$ years at $4 \mathrm{~m}$ and radius from 0.12 to $4.7 \mathrm{~cm}$ at $1 \mathrm{~m}$ and $0.12-3.3 \mathrm{~cm}$ at $4 \mathrm{~m}$. LW width ranged from $0.75 \mathrm{~mm}$ to $5.95 \mathrm{~mm}$ and standard deviation $(0.96 \mathrm{~mm})$ was higher than EW's one $(0.18 \mathrm{~mm})$, ranged $0.10 \mathrm{~mm}-1.15 \mathrm{~mm}$ and LW percentage ranged from $63 \%$ to $96 \%$. But relative standard deviation of $\mathrm{EW}$ reached the highest value, $48 \%$, LW percentage the lowest (7\%) and \%RSD of LW was 34\%.

EW width was found to be the better dependent variable to discriminate coppiced and seeded trees, which is consistent with quantitative anatomy results. Current radius, cambial age and calendar date were considered in independent models because of their collinearity in the data. Their effect on EW width variability was significant at the 0.001 level (Table 1 ). The best fitted model explained $76 \%$ of EW variation $\left(\mathrm{R}^{2}=0.76, \mathrm{~F}_{[12,198]}=52.7, \mathrm{P}<0.001\right)$ and found the following variables to be significant at the 0.001 level: radius, height and interaction between treatment and tree

Table 1

Analysis of variance of earlywood width results. Treatment refers to the two growth strategies, coppiced and seeded trees, df to degrees of freedom and prob. to the Fisher value significance: not significant (ns), $\mathrm{p}<0.05\left(^{*}\right), \mathrm{p}<0.001\left({ }^{* * *}\right)$.

\begin{tabular}{lllll}
\hline Dependant variable & & & & Range \\
\hline EW width & & & & 10 to $115 \mathrm{~mm} \times 100$ \\
\hline Explanatory variables & df & F value & prob. & \\
\hline radius & {$[1,198]$} & 312.5 & $* * *$ & $0.12-4.70 \mathrm{~cm}$ \\
height & {$[1,198]$} & 119.4 & $* * *$ & 1 and $4 \mathrm{~m}$ \\
ring-width & {$[1,198]$} & 0.6 & ns & 95 to $656 \mathrm{~mm} \times 100$ \\
Treatment: tree & {$[9,198]$} & 26.8 & $*^{* * *}$ & \\
age & {$[1,198]$} & 184.6 & $* * *$ & 1 to 15 years \\
height & {$[1,198]$} & 135.1 & $* * *$ & 1 and $4 \mathrm{~m}$ \\
ring-width & {$[1,198]$} & 5.4 & $* *$ & 95 to $656 \mathrm{~mm} \times 100$ \\
Treatment: tree & {$[9,198]$} & 26.9 & $* * *$ & \\
date & {$[1,198]$} & 350.3 & $* * *$ & 1997 to 2011 \\
height & {$[1,198]$} & 0.6 & ns & 1 and $4 \mathrm{~m}$ \\
ring-width & {$[1,198]$} & 2.1 & ns & 95 to $656 \mathrm{~mm} \times 100$ \\
Treatment: tree & {$[9,198]$} & 19.3 & $* * *$ & \\
\hline
\end{tabular}

(Table 1). Ring-width did not present a significant effect in the model in the local settings of quite high means (Table 2A) and variations between 1.7 and $3.2 \mathrm{~mm}$ in coppice and 0.9 minimum, $6.5 \mathrm{~mm}$ maximum in seeded trees.

The increase in EW width related to the increase in radius was highly significant and the slopes differed between coppiced and seeded trees. These slopes and consequently the difference related to the tree groups were not the same at $1 \mathrm{~m}$ and $4 \mathrm{~m}$ high in the stem (Fig. 6). Difference among tree live history was significant in the model and interacted with individual tree variability, thus only this interaction was kept in the simplest model. Finally, EW width was significantly higher in seeded trees $42.5 \pm 19 \mathrm{~mm} \times 100$ than in coppice shoots $34.4 \pm 16 \mathrm{~mm} \times 100$ (Table 2A).

\subsection{Discriminant function}

The linear discriminant function tested includes EW width of one ring and the current radius when this ring is developed. Regardless of the fact that height is significant in the model, samples from $1 \mathrm{~m}$ and $4 \mathrm{~m}$ high were mixed because it was not possible to introduce more than two variables in this function and it is impossible to determine the height provenance of charcoals in archaeological assemblages. Using all the data as for the model calculation, $71 \%$ of rings from coppice shoots were correctly reclassified and 54\% from seeded trees (Fig. 7). EW width increased with radius following different slopes for coppice and seeded trees, thus a new model and discriminant function were calculated on selected data. Restraining the data to radii over $1.66 \mathrm{~cm}$ decreased the error rate from 0.36 to 0.33 , and respectively 77 and $54 \%$ of coppice and seeded trees were correctly reclassified. This better distinction cannot be attributed to an increase in radius difference, as the means of coppice and seeded trees were still close after data had been restrained and the difference between averaged EW widths increased from $21 \%$ to $29 \%$ (Table 2). 
Table 2

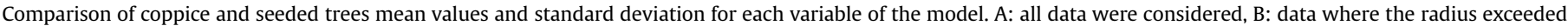
$1.66 \mathrm{~cm}$ were used.

\begin{tabular}{|c|c|c|c|c|}
\hline & \multicolumn{2}{|l|}{ A: all data } & \multicolumn{2}{|c|}{$\mathrm{B}:$ radius $>1.66 \mathrm{~cm}$} \\
\hline & coppice & seeded trees & coppice & seeded trees \\
\hline & mean \pm sd & mean $\pm \mathrm{sd}$ & mean $\pm \mathrm{sd}$ & mean $\pm s d$ \\
\hline radius $(\mathrm{cm})$ & $1.90 \pm 1.14$ & $1.74 \pm 1.13$ & $2.81 \pm 0.78$ & $2.70 \pm 0.75$ \\
\hline height (m) & 1 and $4 \mathrm{~m}$ & 1 and $4 \mathrm{~m}$ & 1 and $4 \mathrm{~m}$ & 1 and $4 \mathrm{~m}$ \\
\hline ring-width $(\mathrm{mm} \times 100)$ & $319 \pm 93$ & $317 \pm 107$ & $343 \pm 105$ & $360 \pm 95$ \\
\hline EW width $(\mathrm{mm} \times 100)$ & $34.4 \pm 16$ & $42.5 \pm 19$ & $41.6 \pm 15$ & $56.0 \pm 17$ \\
\hline
\end{tabular}

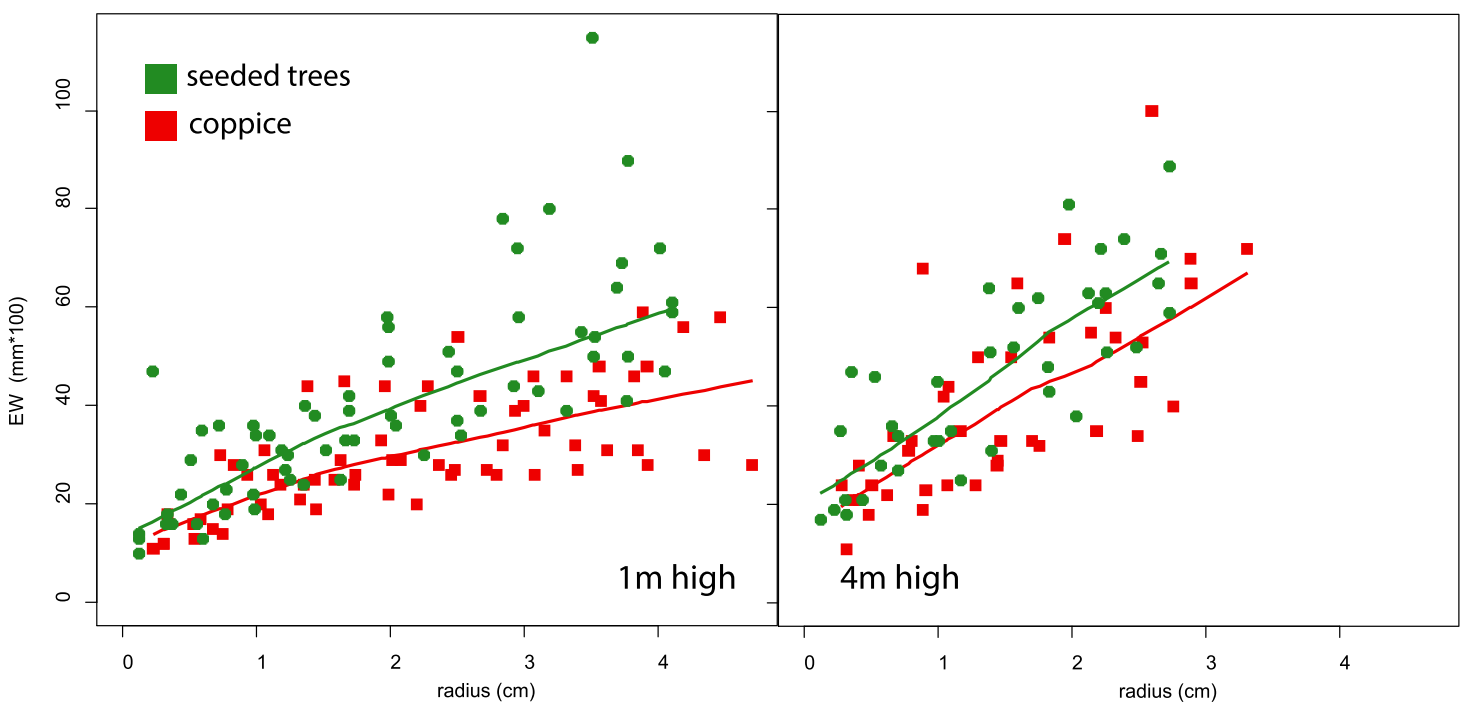

radius $>3.5 \mathrm{~cm}$ of coppice shoot at $1 \mathrm{~m}$ high
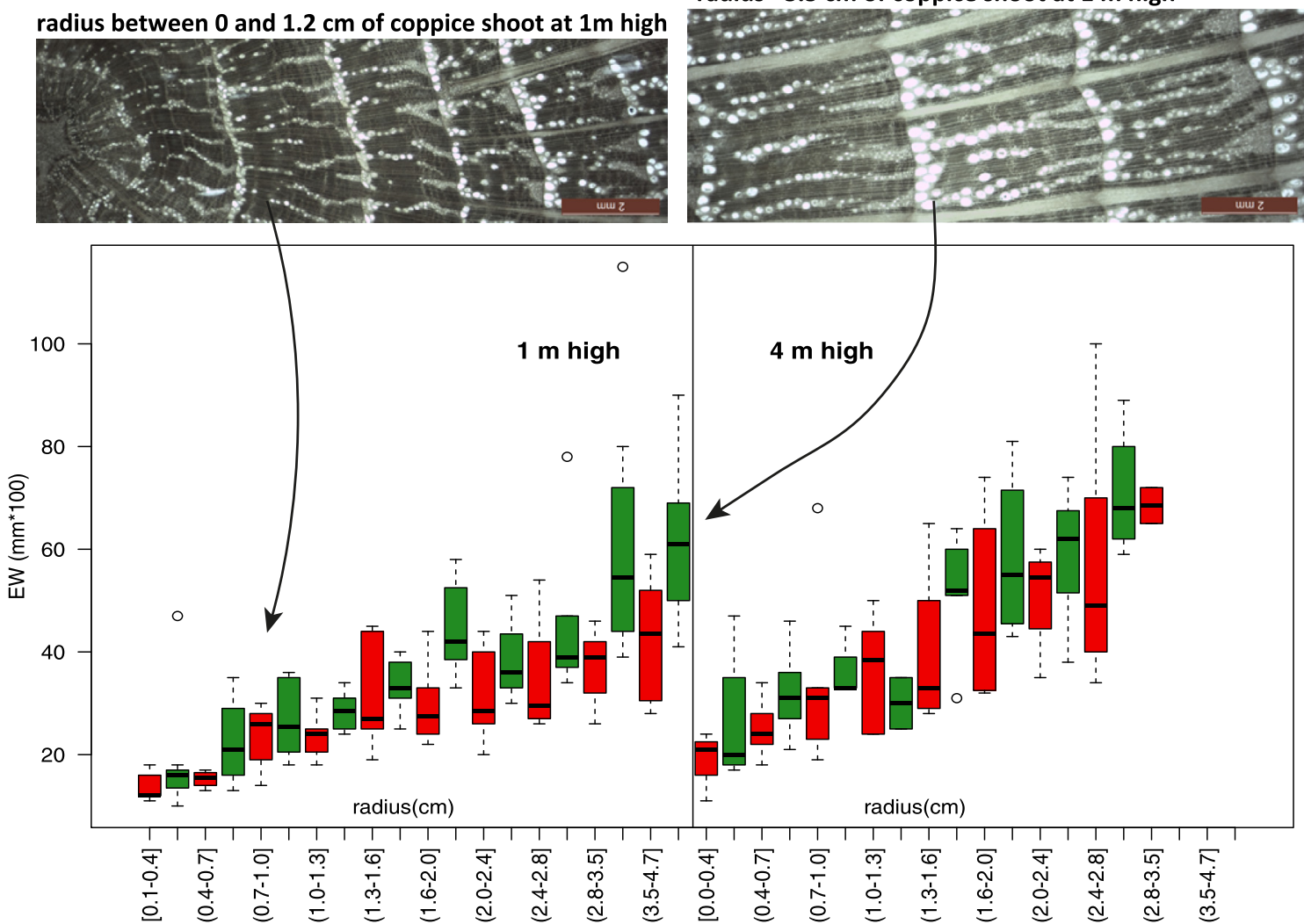

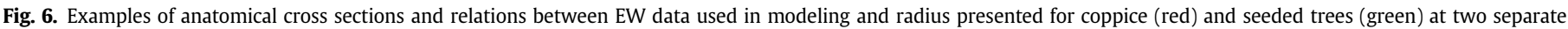

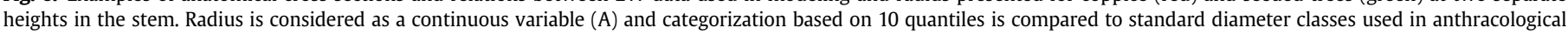
analysis (B). (For interpretation of the references to colour in this figure legend, the reader is referred to the web version of this article.) 

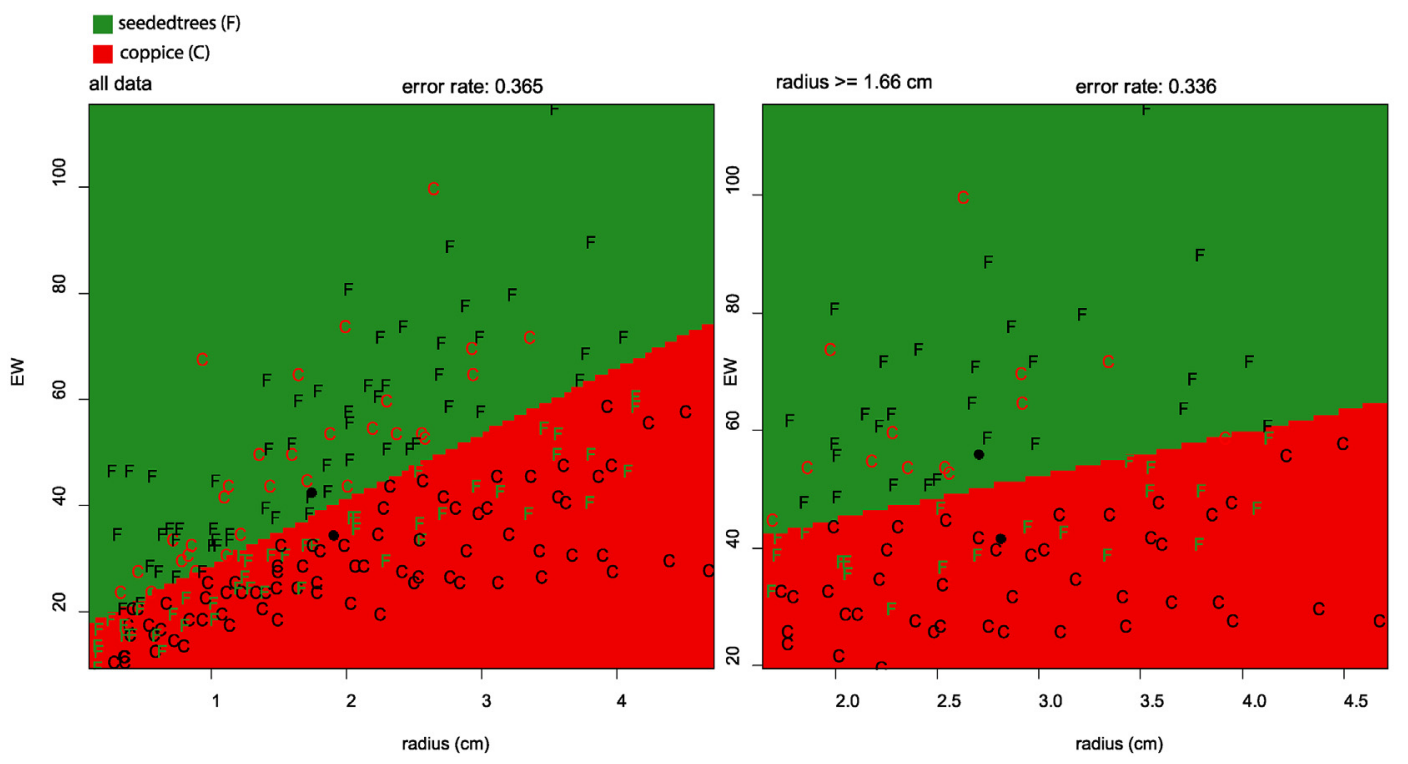

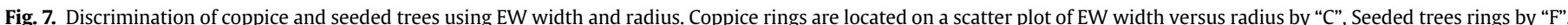

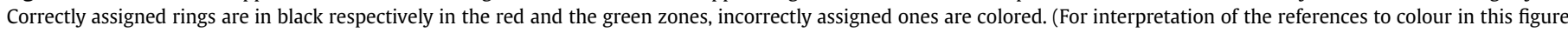
legend, the reader is referred to the web version of this article.)

\section{Discussion}

\subsection{Differences between growth of coppice and seeded sessile oaks}

Radial growth and height evolution with tree age of coppiced and seeded sessile oaks mixed in the same stand were reconstructed by stem analysis. When they had been whole harvested at 15 years old, stems of the same dimensions and under the same fine-scale settings were carefully chosen. In this situation, variability in sprout growth strategy was encountered and can be assumed to be mainly related to the presence or not of belowground biomass and to potential carbohydrate reserve translocation for coppice. The supply of belowground reserve to basal buds after felling was verified for a resprouting species of oak, Quercus pyrenaica (Salomóon et al., 2013, 2016). The coppiced and seeded trees studied here exhibited different growth dynamics to achieve the same dimensions. The coppice stem diameter and height was higher than that of seeded trees until 11 years of age after which they were similar. Coppice shoots grew faster first vertically and then in diameter. The height difference with seeded trees was significant between 3 and 5 years and the diameter difference was significant between 5 and 8 years. The increase in height and diameter of coppice with age followed a somewhat linear trend and only started to slow down when the trees were sampled. To achieve the same dimensions at this stage seeded trees showed a more sigmoid trend. Growth was slower at first but the delay was recovered in a faster period before reaching a slow-down similar to that of coppice.

When even-age structure can be established, wide tree-rings observed near the pith up to the age of 5-10 years followed by a sudden decrease have been suggested as a growth pattern to identify ancient coppice wood (Billamboz, 2003, 2012, 2014; Haneca et al., 2006; Girardclos et al., 2012; Deforce and Haneca, 2015). In our data, differences in ring-width trend related to age between coppice and seeded trees can be divided in three phases: (1) coppice ring-widths are wider, (2) seeded trees develop wider rings and (3) a relative slow-down occurs. These phases are defined based on significant differences at particular years and we can assume that most are related to the presence of belowground biomass after felling coppice. However we did not find in our data a trend as marked as that reported in ancient wood. The mean growth rates calculated for ages of $1-5$ years, namely $2.3 \mathrm{~mm}$ for coppice and $2.0 \mathrm{~mm}$ for seeded trees were not significantly different. We observed an increase of nearly $3.0 \mathrm{~mm}$ in this rate, with no difference between coppiced and seeded trees, until stems were 11 years old, after which a relative decrease in ring-widths occurred but it cannot be considered as sudden. Individual variations in ring-width both for coppiced and seeded trees appeared to be higher during the first $1-3$ years than after, which has been also reported in other site conditions (Copini et al., 2010). The decrease in the ring-widths variability at $4-5$ years coincided with the start of the significantly faster growth in diameter of coppice shoots after having grown faster in height. Our sampling design did not allow us to study the effect of early growth competition between sprouts, but we can assume that the significantly wider rings observed in coppice only after a period of high variability may be related to changes in growth strategy between height and diameter in early stages. The more or less strong decrease in ring-width after 5-10 years, clearly observed in ancient woods, has been related to a rapid increase in competition between shoots and stools in coppice (Billamboz, 2012; Deforce and Haneca, 2015). Shoots from coppices that have not been thinned, mainly because of disinterest for their production, present after 5-8 years much narrower ring-widths than cleared high-forest trees of the same age from the same woodland (Girardclos et al., 2012). However ring-width measurements on living managed coppices are less clear and present high variability (Copini et al., 2010; Deforce and Haneca, 2015). In line with the objective of conversion to high-forest, the coppice of Bois de l'Or was thinned and a single shoot was selected per coppiced stool. The growth trend we observed is likely related to this practice. Further investigations are necessary to take the variety of density conditions combined with coppice and seedling growth strategies into account at a tree level, because growth strategy seems to be related to fine settings of competition and variability at a stand level may therefore be high.

The results discussed above were obtained from the data measured on disks taken at 1-3 m high in stems, under the crown at the stage of growth of the studied trees. There were no 
significant differences in cambial age between coppice and seeded trees above $3 \mathrm{~m}$. Variability in the form of individual stems can be assumed to explain the lack of differences between the two growth strategies in the crown.

Dendrochronological analyses of architectural wood preserved over a great length, i.e. 5-10 m, are not unusual in building studies. In these cases ring-widths can be studied at different heights to identify the basal part of the stem. But our results show that studies of ring-width trend related to cambial age are under constraints since it is not possible to identify height in the stem from charcoal remains.

\subsection{Growth rates cannot be used as a sound indicator of coppiced sessile oaks}

Archaeological round wood remains of fuel-charcoal can exceptionally provide series up to ca. 20 ring-widths. In these cases the trend in ring-width related to cambial age can be compared with the growth patterns of living trees (Deforce and Haneca, 2015), with stronger restrictions on height provenances than for architectural logs studied by dendrochronology. In general, however, dendro-anthracological analyses are constrained to study series of fewer than 10 ring widths located more or less far from the pith. Over a period of nearly a decade, a large part of the ring-width trend can be related to individual events or to the high- to mediumfrequency variability of numerous environmental factors. Therefore ring-widths of the individual fragments are usually averaged to estimate a growth rate. The growth rate has to be associated to the presence of the pith or an estimation of pith distance in order to be interpreted because of the strong influence of age on the value (Dupouey et al., 1992; Marguerie et al., 2010; Dufraisse and GarciaMartinez, 2011). The assumption is made that near the pith the age trend is dominant and that far from the pith environmental factors explain more ring-width variability.

The data from the coppice of Bois de l'Or were tested following this assumption, with the aim of identifying coppice shoots and seeded trees according to growth rates. Ring-width distributions for the whole dataset, regardless of height, distance from the pith and age provenances, from the two growth strategies were found to be the same with a Kruskal-Wallis test $(\mathrm{p}=0.967)$. Although ring widths in the lower part of the stem were significantly wider for coppice at a cambial age of 5-6 years, none of the growth rates calculated for the first centimeters from the pith were significantly different when taking data from all the studied heights into account. Coppice wood could therefore not be distinguished on this basis in our data.

\subsection{Anatomical differences between coppice and seeded sessile oaks}

While growing conditions and selected stems for the coppice and seeded trees were very similar, tree-rings from coppice shoots had smaller but more numerous earlywood vessels per unit area. Because of the strong impact of large vessels in raw sap conduction coppice shoots presented lower hydraulic conductivity than seeded ones.

From wood formation monitoring studies we know that wood cell lumen size is influenced by the age of the cambium (Rossi et al., 2007), the size of the trees (Rathgeber et al., 2011), the position along the stem (Anfodillo et al., 2012), and also the availability of water, carbon, and nutrient reserves (Balducci et al., 2016; Deslauriers et al., 2016). Although these results were obtained on coniferous trees, all these factors very probably also influence oak vessel dimensions. In our case, age of the cambium and availability of reserves are probably the most important factors explaining the anatomical differences between coppice and seeded trees.

\subsection{Additional variables to identify coppice-wood}

Quantitative anatomical analysis showed different ring-patterns for coppice and seeded trees thanks to image analysis of thin sections of fresh wood. The applicability of these results, taking the constraints on archaeological samples from ancient wood, charcoals and dry or waterlogged woods into consideration, was tested on variables that are less time consuming to acquire. In a comparison of 5 coppices from different woodland sites in the center of The Netherlands, Copini et al. (2010) suggested that earlywood width presented a more similar pattern than ring-width. Anatomical analysis showed an earlywood width (EW) difference for the penultimate ring of the coppice and seeded trees. However, EW characteristics, like vessel areas, are also known to be related to age during the juvenile phase (Huber, 1993; Fonti et al., 2009). Considering these results and the constraints of ancient-wood studies, the EW width variability modeling performed in the present study confirmed a strongly significant effect of age for 15-yearold trees. As the studied stand is even-aged, resulting from a clear cut, age and radius (or diameter) are highly correlated and EW variability is explained by the radius at the moment when the ring is formed ( $\mathrm{p}<0.001$ ). EW width increased from about $0.2 \mathrm{~mm}$ for a radius of $1 \mathrm{~cm}$ to $0.5 \mathrm{~mm}$ over $3 \mathrm{~cm}$ which is comparable to the observations by Copini et al. on shoots between 10 and 15 years old. The slope of the relation of EW width with radius is stronger at $4 \mathrm{~m}$ high in the stem than at $1 \mathrm{~m}$, which means that EW width values of around $0.5 \mathrm{~mm}$ are reached for radii of $2 \mathrm{~cm}$. Although EW width is correlated with ring-width, the effect of ring-width in the model including radius and height is not significant, likely indicating that EW width is less related to ring dimension than to ring position in the stem with respect to pith and height.

The relation between EW width and radius differed between coppice and seeded trees. Regardless of radius and heights provenances, the average EW width was significantly greater for seeded trees, which is coherent with a stronger specific hydraulic conductivity estimated by anatomical analysis. Although average EW widths were significantly different between coppice and seeded trees, the variable does not fully discriminate between the two growth strategies. To attempt discrimination, radius was added to EW width in a bivariate linear function. For a relatively large number of charcoal fragments, dendro-anthracological tools provide an estimation of the pith distance, often interpreted in diameter or radius classes (Nelle, 2002; Marguerie et al., 2010; Dufraisse and Garcia-Martinez, 2011). The data have to be used regardless of their height origin, however, because charcoal fragments are assumed to come from various heights in the tree without any possibility of estimation. The discrimination rate provided by this function was nearly $66 \%$ when applied to the data used to construct the model considering rings with a radius over $1.66 \mathrm{~cm}$. EW width differences can be used to recognize part of the coppiced and seeded trees mixed in the same stand while other sources of variability are constrained by sampling. This result offers promising perspectives for dendro-anthracology and dendrochronology. However, material from prehistoric and historical periods has to be considered much more variable. The earlywood variability of oaks between species in the studied region is known to be high (Feuillat et al., 1997) and it can be assumed that differences in stand density and competition resulting from coppice management practices and site productivity conditions have an effect on EW. Nevertheless, Feuillat et al. (1997) provide a basis for the discrimination between $Q$. robur and $Q$. petraea based on specific wood anatomical features. Ancient wood is generally recorded without distinguishing deciduous oak species, both in dendroarchaeological 
and anthracological studies. As a first attempt to observe differences in wood anatomy related to coppicing we constrained most of the other sources of variance in our sampling, including oak species. Studies of living oaks from different species are therefore needed in each biogeographical context where an application in the past of these results is sought.

\section{Conclusion}

To date, no studies have been conducted from an archaeological perspective to compare the growth and wood anatomy of coppiced and seeded living oak stems developing in the same stand. The comparison of coppiced and seeded 15-year-old Quercus petraea mixed in the same stand contributes to improving the recognition of ancient coppice wood. Coppice and seeded trees have different growth trajectories even if samples are chosen in very similar fine-scale settings. The growth of coppice shoots followed a linear progression while seeded trees showed a more sigmoid trend to achieve similar dimensions at the time of sampling. Coppice grew first faster in height and second in diameter. In similar stand conditions, differences can likely be related to the availability of a belowground reserve after felling for coppice. The resulting wood anatomy presented significant earlywood differences: tree-rings from coppice shoots had smaller and more numerous vessels, but a lower total proportion of conducting tissue and lower hydraulic conductivity than seeded trees. Consistent with vessels anatomy, earlywood width was greater in seeded trees and modeling its variability showed strong effects of radius and height. Taking into account the constraints on dendro-anthracological material, earlywood width and radius were used in a discriminant function which correctly assigned two-thirds of the two growth strategies when the radius exceeded $1.66 \mathrm{~cm}$.

An age-related growth pattern consisting of wide rings from near the pith to 5-10 years followed by a rapid ring-width decrease is observed in numerous ancient wood studies whether from fuelwood or timber wood remains. Based on comparisons with livingtrees ring-width studies, this pattern has been used to identify wood from coppice associated with even-age structure and archaeological features such as the standardization of log and final product dimensions. The age-related trend of Bois de L'Or coppice shoots ring-width showed high individual variability immediately from the pith and wider rings only for the years 5 and 6 . These wide rings were not followed by a rapid decrease and in a second phase seeded trees grew faster than coppice. The reported growth patterns are likely linked to bud growth, to the stand thinning conditions and to sampling choice. The diameter and height growth patterns observed in the present study suggest that in the very early stage of buds' life history, the influence of the potential reserve available and that of competition dynamics are closely intertwined.

The anatomical differences observed between coppice and seeded trees while other sources of variability were constrained by sampling cannot allow a complete discrimination in much more variable samples from archaeological contexts, but nonetheless provide perspectives for improving the identification of ancient woods from coppice based on the ring anatomy, growth patterns and archaeological features.

\section{Acknowledgment}

This work was funded by grants from the Agence Nationale de la Recherche (ANR JCJC 200101 DENDRAC, dir. A. Dufraisse). We thank Elizabeth Rowley-Jolivet for her help with the English.

\section{References}

Anfodillo, T., Deslauriers, A., Menardi, R., Tedoldi, L., Petit, G., Rossi, S., 2012. Widening of xylem conduits in a conifer tree depends on the longer time of cell expansion downwards along the stem. J. Exp. Bot. 63, 837-845. http:// dx.doi.org/10.1093/jxb/err309.

Balducci, L., Cuny, H.E., Rathgeber, C.B.K., Deslauriers, A., Giovannelli, A., Rossi, S. 2016. Compensatory mechanisms mitigate the effect of warming and drought on wood formation: wood formation under warming and drought. Plant Cell Environ. 39, 1338-1352. http://dx.doi.org/10.1111/pce.12689.

Becker M. Nieminen, TM. Geremia, F. 1994. Short-term variations and long-term changes in oak productivity in northeastern France. The role of climate and atmospheric $\mathrm{CO}_{2}$. In: Annales Des Sciences Forestières. EDP Sciences, pp. 477-492.

Bernard, V., Billard, C., Couturier, Y., Jaouen, G., LeDigol, Y. 2012. Quand nos ancêtres allaient au pieu: des chaines de production forestière du Bronze ancien tournées vers le taillis. In: Mélin, M., Mougne, C. (Eds.), L'Homme, Ses Ressources et Son Environnement, Dans Le Nord-Ouest de La France à L'âge Du Bronze: Actualités de La Recherche, Actes Du Séminaire Archéologique de l'Ouest Du 22 Mars 2012, Mémoire de Géosciences Hors-Série N`8, pp. 27-58. éditions de Géosciences Rennes.

Billamboz, A., 2014. Regional patterns of settlement and woodland developments: dendroarchaeology in the Neolithic pile-dwellings on Lake Constance (Germany). Holocene 24, 1278-1287. http://dx.doi.org/10.1177/0959683614540956.

Billamboz, A. 2012. Les villages néolithiques de la baie de Sipplingen sur le lac de Constance: rythmes de l'occupation dans le contexte de l'économie forestière. In: Honegger, M., Mordant, C. (Eds.), L'Homme Au Bord de L'eau;: Archéologie Des Zones Littorales Du Néolithique à La Protohistoire, Actes Du 135e Congrès National Des Sociétés Historiques et Scientifiques Du CTHS «Paysages», 6-11 Avril 2010 à Neuchâtel, Cahier d'Archéologie Romande 132 Documents Préhistoriques 30. Neuchâtel, pp. 299-314.

Billamboz, A., 2003. Tree rings and wetland occupation in southwest Germany between 2000 and 500 BC: dendroarchaeology beyond dating. Tree Ring Res. 59 (1), 37-49 (Tribute to F. H. Schweingruber).

Bleicher, N., 2007. Dendroarchaeology of late-neolithic timber in the Federseebasin. In: Haneca, K. Verheyden, A., Beeckman, H., Gärtner, H., Helle, G., Schleser, G. (Eds.), TRACE Tree Rings in Archaeology, Climatology and Ecology Volume 5 Proceedings of the DENDROSYMPOSIUM, April 20th - 22nd 2006, Tervuren, Belgium, Schriften des Forschungszentrums Jülich, Reihe Umwelt, vol. 74, pp. 28-34.

Bond, W.J., Midgley, J.J., 2003. The evolutionary ecology of sprouting in woody plants. Int. J. Plant Sci. 164, S103-S114. http://dx.doi.org/10.1086/374191.

Buridant, J., 2004. Du "modèle" à la pratique;: la gestion des peuplements caducifoliés dans la France Moderne, XVIe-XVIIIe siècle. In: Corvol-Dessert, A (Ed.), Les Forêts d'Occident Du Moyen-âge à Nos Jours. Presse Universitaires du Mirail, Toulouse, pp. 203-220.

Burns, R.-M., Honkala, B.-H. (Eds.), 1990. Silvics of North America: 1. Conifers; 2. Hardwoods. Agriculture Handbook, vol. 654. U.S. Dept. of Agriculture, Forest Service, Washington, D.C.

Clarke, P.J., Lawes, M.J., Midgley, J.J., Lamont, B.B., Ojeda, F., Burrows, G.E. Enright, N.J., Knox, K.J.E., 2013. Resprouting as a key functional trait: how buds, protection and resources drive persistence after fire. New Phytol. 197, 19-35. http://dx.doi.org/10.1111/nph.12001.

Copini, P., Sass-Klaassen, U., Den Ouden, J., 2010. Coppice fingerprints in growth patterns of pedunculate oak (Quercus robur). In: Levanič, T., Gricar, J., Hafner, P. Krajnc, R., Jagodic, S., Gärtner, H., Heinrich, I., Helle, G. (Eds.), TRACE - Tree Rings in Archaeology, Climatology and Ecology, Proceedings of the DEN DROSYMPOSIUM 2009, April 16th - 19th 2009 in Otocec. Slovenia, pp. 54-60.

Corvol-Dessert, A., 2002. La récolte en bois d'oeuvre: une insuffisance chronique. In: Hoffsummer, P., Meyer, J. (Eds.), Les Charpentes Du XIe Au XIXe Siècle, Typologie et évolution En France Du Nord et En Belgique. Monum, pp. 41-53.

Crockford, K.J., Savill, P.S., 1991. Preliminary yield tables for Oak coppice. Forestry 64, 29-49.

Davasse, B., 2000. Forêts charbonniers et paysans dans les Pyrénées de l'est du Moyen-âge à nos jours. In: UMR GEODE, Conseil Général Ariège (Ed.), Une approche géographique de l'histoire de l'environnement.

Deforce, K., Boeren, I., Adriaenssens, S., Bastiaens, J., De Keersmaeker, L., Haneca, K. Tys, D., Vandekerkhove, K., 2013. Selective woodland exploitation for charcoal production. A detailed analysis of charcoal kiln remains (ca. 1300-1900 AD) from Zoersel (northern Belgium). J. Archaeol. Sci. 40, 681-689. http:// dx.doi.org/10.1016/j.jas.2012.07.009.

Deforce, K., Haneca, K., 2015. Tree-ring analysis of archaeological charcoal as a tool to identify past woodland management: the case from a 14th century site from Oudenaarde (Belgium). Quat. Int. 366, 70-80. http://dx.doi.org/10.1016 j.quaint.2014.05.056.

Del Tredici, P., 2001. Sprouting in temperate trees: a morphological and ecological review. Bot. Rev. 67, 121-140.

Deslauriers, A., Huang, J.-G., Balducci, L., Beaulieu, M., Rossi, S., 2016. The contribution of carbon and water in modulating wood formation in black spruce saplings. Plant Physiol. 170, 2072-2084. http://dx.doi.org/10.1104/pp.15.01525.

Dufraisse, A. Coubray, S., Girardclos, O., Nocus, N., Lemoine, M., Dupouey, J.-L, Marguerie, D., 2017. submitted. Anthraco-typology as a key approach to past firewood exploitation and woodland management reconstructions. Dendrological reference dataset modelling with dendro-anthracological tools 
(submitted for publication). Quat. Int. (this volume).

Dufraisse, A., Gauthier, E., 2002. Exploitation des sources salées en Franche-Comté: impact sur l'espace forestier du Néolithique à la période médiévale. In: Weller, O. (Ed.), Archéologie Du Sel: Techniques et Sociétés, pp. 243-267.

Dufraisse, A., Garcia-Martinez, M.-S., 2011. Mesurer les diamètres du bois de feu en anthracologie. Outils dendrométriques et interprétation des données. Anthropobotanica $2,1-18$

Duhamel Du Monceau, H.L., 1764. De l'exploitation des bois, ou Moyens de tirer un parti avantageux des taillis, demi-futaies et hautes-futaies. In: Guérin, H.-L., Delatour, L.-F. (Eds.) (Paris)

Dupin, A., Girardclos, O., Laplaige, C., Fruchard, C., Nuninger, L., Dufraisse, A., Gauthier, E., 2017. submitted. Anthracology of charcoal kilns in the forest of Chailluz (France) as a tool to understand Franche-Comté forestry from the mid15th to the early 20th century (submitted for publication). Quat. Int. (this volume).

Dupouey, J.-L., Denis, J.B., Becker, M., 1992. A new method of standardization for examining long term trends in tree-ring chronologies. Lundqua Rep. 34, 85-88.

Epaud, F., Bernard, V., 2008. L'évolution des charpentes d'églises du Val d'Oise, du XIe au XXe siècle. Rev. Archéol. Cent. Fr. 47, 1-34.

Feuillat, F., Dupouey, J.-L., Sciama, D., Keller, R., 1997. A new attempt at discrimination between Quercus petraea and Quercus robur based on wood anatomy. Can. J. For. Res. 27, 343-351.

Fonti, P., Treydte, K., Osenstetter, S., Frank, D., Esper, J., 2009. Frequency-dependent signals in multi-centennial oak vessel data. Palaeogeogr. Palaeoclimatol. Palaeoecol. 275, 92-99. http://dx.doi.org/10.1016/j.palaeo.2009.02.021.

Girardclos, O., Billamboz, A., Gassmann, P., 2012. Abandoned Oak coppice on both sides of the Jura Mountains: dendroecological growth models highlighting woodland development and management in the past. In: Gärtner, H. Rozenberg, P., Montès, P., Bertel, O., Heinrich, I., Helle, G. (Eds.), TRACE Tree Rings in Archaeology, Climatology and Ecology Volume 10 Proceedings of the DENDROSYMPOSIUM 2011 May 11th - 14th, 2011 in Orléans, France. Deutsches GeoForschungsZentrum GFZ, Potsdam, pp. 71-78.

Haneca, K., Boeren, I., Van Acker, J., Beeckman, H., 2006. Dendrochronology in suboptimal conditions: tree rings from medieval oak from Flanders (Belgium) as dating tools and archives of past forest management. Veg. Hist. Archaeobot. $15,137-144$.

Huber, F. 1993. Déterminisme de la surface des vaisseaux du bois des chênes indigènes (Quercus robur L, Quercus petraea Liebl). Effet individuel, effet de l'appareil foliaire, des conditions climatiques et de l'âge de l'arbre. Ann. Des. Sci. For. 50, 509-524.

Marguerie, D., Bernard, V., Bégin, Y., Terral, J.F., 2010. Dendroanthracologie. In: Payette, S., Filion, L. (Eds.), La Dendroécologie, Principes, Méthodes et Applications, pp. 311-347. Québec.

Marguerie, D., Hunot, J.-Y., 2007. Charcoal analysis and dendrology: data from archaeological sites in north-western France. J. Archaeol. Sci. 34, 1417-1433. http://dx.doi.org/10.1016/j.jas.2006.10.032

Nelle, O., 2002. Charcoal burning remains and forest stand structure. Examples from black forest (South-West Germany) and bavarian forest (South-Est Germany). In: Thiébault, S. (Ed.), Proceedings of the Second International Meeting of Anthracology, Paris, pp. 201-207.

Paradis-Grenouillet, S., Allée, P., Vives, G.S., Ploquin, A., 2015. Sustainable management of metallurgical forest on Mont Lozère (France) during the early middle ages. Environ. Archaeol. 20, 168-183. http://dx.doi.org/10.1179/ 1749631414 Y.0000000050.

Payette, S., Delwaide, A., 2010. Analyse de tige. In: Payette, S., Filion, L. (Eds.), La Dendroécologie, Principes, Méthodes et Applications, pp. 255-282. Québec.

Rackham, O., 2003. Ancient Woodland: its History, Vegetation and Uses in England. Castlepoint Press, Colvend.

Rathgeber, C.B.K., Rossi, S., Bontemps, J.-D., 2011. Cambial activity related to tree size in a mature silver-fir plantation. Ann. Bot. 108, 429-438. http://dx.doi.org/ 10.1093/aob/mcr168.

Rinn, F., 1989. TSAP, Time Series Analysis and Presentation, Version 3.0 Reference Manual. RinnTech, Heidelberg.

Rossi, S., Deslauriers, A., Anfodillo, T., Carrer, M., 2007. Age-dependent xylogenesis in timberline conifers. New Phytol. http://dx.doi.org/10.1111/j.14698137.2007.02235.x, 0, 071018051611001-???

Salomón, R. Rodríguez-Calcerrada, J., Zafra, E., Morales-Molino, C., RodríguezGarcía, A., González-Doncel, I., Oleksyn, J., Zytkowiak, R., López, R., Miranda, J.C., Gil, L., Valbuena-Carabaña, M., 2016. Unearthing the roots of degradation of Quercus pyrenaica coppices: a root-to-shoot imbalance caused by historical management? For. Ecol. Manag. 363, 200-211. http://dx.doi.org/10.1016/ j.foreco.2015.12.040

Salomón, R., Valbuena-Carabaña, M., Gil, L., González-Doncel, I., 2013. Clonal structure influences stem growth in Quercus pyrenaica Willd. coppices: bigger is less vigorous. For. Ecol. Manag. 296, 108-118. http://dx.doi.org/10.1016/ j.foreco.2013.02.011.

Splichalova, M., Adamec, Z., Kadavy, J., Kneifl, M., 2012. Probability model of sessile oak (Quercus petraea (Matt.) Liebl.) stump sprouting in the Czech Republic. Eur. J. For. Res. 131, 1611-1618. http://dx.doi.org/10.1007/s10342-012-0628-3.

Svatek, M., Matula, R., 2015. Fine-scale spatial patterns in oak sprouting and mortality in a newly restored coppice. For. Ecol. Manag. 348, 117-123. http:// dx.doi.org/10.1016/j.foreco.2015.03.048.

Tyree, M.T., Ewers, F.W., 1991. The hydraulic architecture of trees and other woody plants. New Phytol. 119, 345-360. http://dx.doi.org/10.1111/j.14698137.1991.tb00035.x.

Venables, W.N., Ripley, B.D., 2002. Modern Applied Statistics with S, Fourth. ed. Springer, New York. 